\title{
Review
}

\section{BDNF and Activity-Dependent Synaptic Modulation}

\author{
Bai Lu ${ }^{1}$ \\ Section on Neural Development and Plasticity, National Institute of Child Health and Human Development (NICHD), National Institutes \\ of Health (NIH), Bethesda, Maryland, 20892-4480, USA
}

\begin{abstract}
It is widely accepted that neuronal activity plays a pivotal role in synaptic plasticity. Neurotrophins have emerged recently as potent factors for synaptic modulation. The relationship between the activity and neurotrophic regulation of synapse development and plasticity, however, remains unclear. A prevailing hypothesis is that activity-dependent synaptic modulation is mediated by neurotrophins. An important but unresolved issue is how diffusible molecules such as neurotrophins achieve local and synapse-specific modulation. In this review, I discuss several potential mechanisms with which neuronal activity could control the synapse-specificity of neurotrophin regulation, with particular emphasis on BDNF. Data accumulated in recent years suggest that neuronal activity regulates the transcription of BDNF gene, the transport of BDNF mRNA and protein into dendrites, and the secretion of BDNF protein. There is also evidence for activity-dependent regulation of the trafficking of the BDNF receptor, TrkB, including its cell surface expression and ligand-induced endocytosis. Further study of these mechanisms will help us better understand how neurotrophins could mediate activity-dependent plasticity in a local and synapse-specific manner.
\end{abstract}

Much of the brain's ability to adapt or modify itself in response to experience and environment lies in the plasticity of synaptic connections, both short- and long- terms. Substantial evidence indicates that the number and the strength of synapses can be changed by neuronal activity (Bliss and Collingridge 1993; Linden 1994; Malenka and Nicoll 1999; McEwen 1999). It is now widely accepted that activity-dependent modulation of synapses is critical for brain development as well as many cognitive functions in the adult. Molecular mechanisms that translate patterns of neuronal activity into specific changes in the structures and function of synapses, however, remain largely unknown. A hypothesis was put forward several years ago that neurotrophins may serve as molecular mediators for synaptic plasticity based on two observations: (1) The expression of neurotrophins is regulated by neuroelectric activity; and (2) neurotrophins could modulate the efficacy of synaptic transmission or the growth of dendrites and axons, the structural elements necessary for synaptogenesis (Thoenen 1995; Berninger and Poo 1996; Bonhoeffer 1996; Katz and Shatz 1996; Lu and Figurov 1997). It was proposed that neuronal activity would enhance local synthesis/secretion of neurotrophins, which would in turn regulate synaptic efficacy or growth. This simple idea was very attractive to scientists in both the neurotrophin and plasticity fields. The convergence of the two fields has brought an exciting new area of research-neurotrophic regulation of synapse development

${ }^{1}$ E-MAIL bailu@mail.nih.gov; FAX (301) 496-1777. Article and publication are at http://www.learnmem.org/cgi/doi/ $10.1101 / \mathrm{lm} .54603$. and plasticity. There has been a rapid growth of this area in recent years. It is now widely accepted that neurotrophins have a crucial role in synaptic transmission and plasticity. As many growing fields, enthusiastic efforts by scientists with different backgrounds and expertise have generated more questions than answers, and these efforts are likely to bring in many new and unexpected findings.

Neurotrophins belong to a family of secretory proteins that include nerve growth factor (NGF), brain-derived neurotrophic factor (BDNF), neurotrophin-3 (NT-3), and NT-4/ 5 . These proteins initiate their biological functions by interacting with their cognate receptors. All neurotrophins bind to the p75 neurotrophin receptor (p75NR) (Chao 1992), and each neurotrophin also binds to a specific Trk receptor tyrosine kinase: NGF binds to TrkA; BDNF and NT- $4 / 5$ to TrkB; and NT-3 to TrkC (Barbacid 1993). So far, all the synaptic functions of neurotrophins seem to be mediated by the Trk receptors. Ligand binding results in dimerization and autophosphorylation of the Trk receptors, leading to activation of the tyrosine kinases. Activated receptors in general are capable of triggering a number of signal transduction cascades including the MAPK pathway, the phosphatidylinositol 3-kinase (PI3K) pathway, and the phospholipase C- $\gamma$ (PLC- $\gamma$ ) pathway (Kaplan and Miller 2000; Patapoutian and Reichardt 2001). These signals then pass on to the nucleus to activate transcription factors that alter gene expression. Although for decades neurotrophins have been viewed as major regulators for neuronal survival and differentiation during embryonic development and maintenance of viability of neurons in adulthood (Levi-Montalcini 1987; Lewin and Barde 1996; Huang and Reichardt 2001), there is

LEARNING \& MEMORY 10:86-98 @ 2003 by Cold Spring Harbor Laboratory Press ISSN1072-0502/03 \$5.00

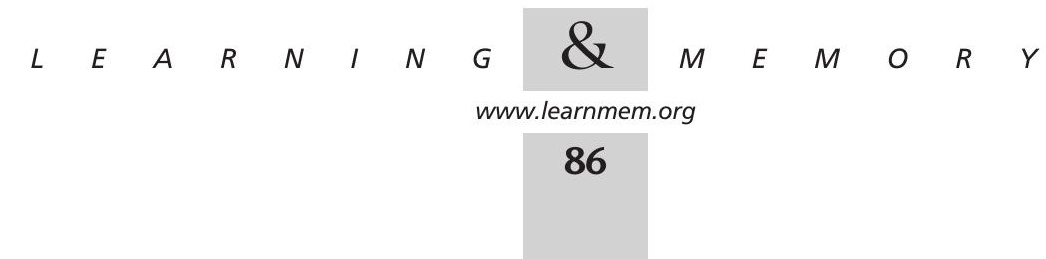


no doubt that these factors are also important for the development and function of synapses.

The synaptic function of neurotrophins was first discovered at the neuromuscular junction (NMJ) in vitro. Application of BDNF, or NT3 to the neuromuscular synapses, elicits a rapid enhancement of transmitter release (Lohof et al. 1993; Stoop and Poo 1995). The synthesis of NT3 and secretion of NT4 from the postsynaptic muscle cells increase rapidly in response to presynaptic activity (Wang and Poo 1997; Xie et al. 1997). The acute effect of neurotrophins occurs preferentially to active synapses and requires cAMP as a gate (Boulanger and Poo 1999a,b). Moreover, such regulation requires a cascade of protein phosphorylation events (He et al. 2000; Yang et al. 2001), and is independent of new protein synthesis (Stoop and Poo 1995; Chang and Popov 1999). At hippocampal CA1 synapses, substantial evidence indicates that BDNF acutely facilitates long-term potentiation (LTP) (Korte et al. 1995; Figurov et al. 1996; Patterson et al. 1996). This effect is caused primarily to a presynaptic mechanism (Gottschalk et al. 1998; Xu et al. 2000) and has been attributed to a potentiation of synaptic responses to tetanic stimulation and an enhancement of synaptic vesicle docking, possibly through changes in the levels and/or phosphorylation of synaptic proteins (Gottschalk et al. 1999; Pozzo-Miller et al. 1999; Jovanovic et al. 2000). Postsynaptic effects of BDNF on dentate LTP in slices and on NMDA receptors in cultured hippocampal neurons have also been reported (Levine et al. 1998; Kovalchuk et al. 2002). In the visual cortex, BDNF has been shown to facilitate LTP (Akaneya et al. 1997; Huber et al. 1998; Jiang et al. 2001) and attenuates LTD in layer II/III synapses of young adult rats (Akaneya et al. 1996; Huber et al. 1998; Kinoshita et al. 1999; Kumura et al. 2000).

In addition to their acute effects on synaptic transmission and plasticity, neurotrophins also exhibit a long-term regulatory role in synapse development and function. Longterm application of neurotrophins exerts complex modulation of dendritic and axonal growth in the brain, particularly in the visual system (Cohen-Cory and Fraser 1995; McAllister et al. 1995). Neurotrophins are involved in activity-dependent synaptic competition and formation of ocular dominance columns in the visual cortex (Maffei et al. 1992; Cabelli et al. 1995; Huang et al. 1999). Substantial evidence suggests that neurotrophins promote the maturation of the neuromuscular synapses in vitro and in vivo (Wang et al. 1995; Liou and Fu 1997; Gonzalez et al. 1999; Nick and Ribera 2000). Long-term regulation of synaptic transmission by neurotrophins has also been observed in glutamatergic and GABAergic synapses in the central nervous system (CNS) (Rutherford et al. 1998; Vicario-Abejon et al. 1998; Huang et al. 1999; Sherwood and Lo 1999). Interestingly, the long-term synaptic effects of BDNF in hippocampal slices appear to be dependent on cAMP and new protein synthesis (Tartaglia et al. 2001), characters reminiscent of late phase LTP (L-LTP) and long-term memory seen in many model systems.

The synaptic functions of neurotrophins have been covered in some detail by a number of recent reviews (Lu and Chow 1999; McAllister et al. 1999; Schuman 1999; Poo 2001). This review addresses the relationship between neuronal activity and neurotrophins in synaptic modulation. I have primarily focused on BDNF because it has been studied most extensively. I describe how neuronal activity regulates the transcription of BDNF gene, the transport of BDNF mRNA, and the secretion of BDNF protein. I also discuss evidence for activity-dependent modulation of trafficking of the BDNF receptor, TrkB. Efforts have been made to put complex and sometimes conflicting results into perspective. I believe that these recent studies may provide important insights into how synapse-specific modulation could be achieved by diffusible molecules, such as BDNF.

\section{Possible Mechanisms for Local and Synapse- Specific Modulation by Neurotrophins}

The studies described above strongly suggest an intimate relationship between neuronal activity and neurotrophins in the modulation of synapse structures and functions. Thus, neurotrophins have been proposed to mediate activity-dependent synaptic potentiation in the CNS (Thoenen 1995; Berninger and Poo 1996; Bonhoeffer 1996; Katz and Shatz 1996; Lu and Figurov 1997). This hypothesis is particularly attractive for homosynaptic and associative LTPs because it links patterned neuronal activity to molecular signals that control synaptic efficacy and connectivity. To qualify neurotrophins as mediators for these types of synaptic potentiation, however, two key issues must be addressed. First, because many forms of activity-dependent plasticity occur in a local and synapse-specific manner (Stent 1973; Bliss and Collingridge 1993; Linden 1994; Malenka and Nicoll 1999), neurotrophins should act locally to translate the effect of neuronal activity into structural and functional changes in specific synapses. In a number of carefully designed studies, such local and synapse-specific effects of neurotrophins have been demonstrated. For example, whereas focal application of NT3 to any part of motor neurons could elicit acute synaptic potentiation (Chang and Popov 1999), BDNF must be applied to the synapse, not cell body, to elicit its acute effect (Stoop and Poo 1995). When a motor neuron innervates two myocytes, one of which over-expresses NT4, synaptic potentiation is restricted to the NT4-expressing synapses without spreading to the control synapse made by the same presynaptic neuron as close as $60 \mu \mathrm{m}$ away (Wang et al. 1998). In hippocampal cultures, application of BDNF preferentially potentiates immature synapses with lower release probability without affecting nearby mature synapses (Lessmann and Heumann 1998; Berninger et al. 1999). The effect of BDNF may also be limited to specific postsynaptic targets. In a

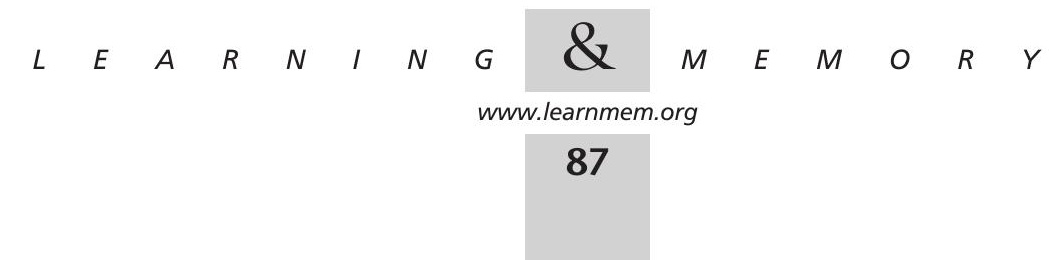


single excitatory neuron innervating both glutamatergic and GABAergic neurons, BDNF selectively potentiates the synapses with glutamatergic, but not GABAergic, neurons as their postsynaptic partners (Schinder et al. 2000). When two sets of Schaffer collaterals-CA1 synapses in the same hippocampal slice are monitored simultaneously, BDNF treatment potentiates the tetanized pathway without affecting the synaptic efficacy of the untetanized pathway (Gottschalk et al. 1998). These results indicate that BDNF effects could be spatially restricted and selective to certain specific synapses.

The second key issue is how BDNF can act preferentially on active synapses. The widely accepted Hebb's hypothesis predicts that more active synapses are favored during synaptic competition (Stent 1973). If diffusible neurotrophins are to mediate the activity-dependent synaptic potentiation, they must be able to distinguish the active and inactive synapses that are right next to each other. One way to achieve this is to have activity-dependent control of the synaptic responsiveness to neurotrophins. A number of recent experiments suggest that at least for BDNF, this may be a plausible mechanism. For example, presynaptic depolarization greatly facilitates BDNF modulation of synaptic transmission at the neuromuscular junction (Boulanger and Poo $1999 \mathrm{~b})$. The survival effect of BDNF on retinal ganglion neurons requires depolarization by high $\mathrm{K}^{+}$or glutamate agonists, or an elevation of intracellular cAMP (MeyerFranke et al. 1995). In the hippocampus, the effect of BDNF on synaptic responses to repetitive stimulation at CA1 synapses is observed only when presynaptic neurons are stimulated at high frequency (Gottschalk et al. 1998). Moreover, pairing of BDNF with neuronal activity appears to be more effective in inducing long-term synaptic potentiation. At CA1 synapses, weak tetanus induces only short-term potentiation of low magnitude, but strong LTP when paired with BDNF application (Figurov et al. 1996). At dentate synapses, pairing of a brief puff of BDNF with a weak presynaptic stimulation elicits a robust LTP (Kovalchuk et al. 2002). The selective pairing of BDNF and high-frequency neuronal activity could potentially provide the signal for coincidence detection. In the visual cortex, regulation of dendritic arborization in the visual cortex by $\mathrm{BDNF}$ requires neuronal activity and $\mathrm{Ca}^{2+}$ influx through NMDA receptors (McAllister et al. 1996). Taken together, these results support the notion that BDNF preferentially regulates synapses with higher activity levels.

The local and synapse-specific modulation, together with preference in active neurons/synapses, suggests that neurotrophins must preferentially regulate active synapses with little or no effect on nearby less active synapses. As a diffusible molecule, how could BDNF distinguish active and inactive neurons or synapses? In the following sections, I discuss experimental data that demonstrate various ways by which BDNF restricts its biological effects to active syn- apses. First, the transcription of BDNF could be regulated by neuronal activity (Fig. 1A). This phenomenon has been repeatedly observed in the many different populations of neurons in the CNS (Thoenen 1995; McAllister et al. 1999). As transcription must occur in the cell body, BDNF mRNA needs to be either actively transported or passively trapped at specific synapses. Activity-dependent dendritic targeting of BDNF mRNA and its local translation may be one solution for this conundrum (Fig. 1A). Second, activity-dependent secretion of BDNF could occur locally at the site of active synapses, with mechanisms that limit its diffusion (Fig. 1B). BDNF is a sticky molecule with limited diffusion capacity. Truncated TrkB molecules are highly expressed in the cell surface of mature CNS neurons may also limit BDNF diffusion (Biffo et al. 1995; Fryer et al. 1996; McAllister et al. 1999). Third, active neurons/synapses may respond better to BDNF compared to inactive ones, and this could be achieved by an activity-dependent control of the number of TrkB receptors on the cell surface (Fig. 1C). Cell surface insertion of TrkB receptors appears to be enhanced by excitatory synaptic activity, suggesting local insertion of TrkB at active synapses (Du et al. 2000). Finally, neuronal activity could also facilitate the internalization of BDNF-receptor complex (Fig. 1D), which is a key signaling event that mediates many of the BDNF functions.

\section{Activity-Dependent BDNF Transcription and Local Translation}

The idea for an activity-dependent transcription of BDNF gene was first supported by the findings that BDNF mRNA expression in the hippocampus is dramatically increased in animals undergoing experimental seizure (Zafra et al. 1990; Ernfors et al. 1991; Isackson et al. 1991; Dugich-Djordjevic et al. 1992). Subsequently, the level BDNF mRNA has been shown to increase markedly by LTP-inducing tetanic stimulation, with little or no effects on other neurotrophins (Patterson et al. 1992; Castren et al. 1993; Dragunow et al. 1993; Kesslak et al. 1998; Morimoto et al. 1998). This observation has inspired the efforts to correlate BDNF mRNA expression with learning and memory (Falkenberg et al. 1992; Kesslak et al. 1998; Hall et al. 2000; Mizuno et al. 2000). Enriched environment also enhances BDNF gene expression (Young et al. 1999; Ickes et al. 2000; Zhao et al. 2001). In the visual cortex, the expression of BDNF, but not NGF, in the visual cortex is regulated by visual inputs (Castren et al. 1992; Schoups et al. 1995; Pollock et al. 2001), and monocular activity blockade elicits a striking decrease in BDNF mRNA and protein in the visual cortex corresponding the deprived eye (Bozzi et al. 1995; Rossi et al. 1999; Lein and Shatz 2000). Sensory stimulation of whiskers enhances the expression of BDNF in the barrel cortex (Rocamora et al. 1996; Nanda and Mack 2000). Other physiologically relevant stimuli, such as physical activity and running (Neeper et al. 1996; Oliff et al. 1998; Russo-Neustadt et al. 1999;

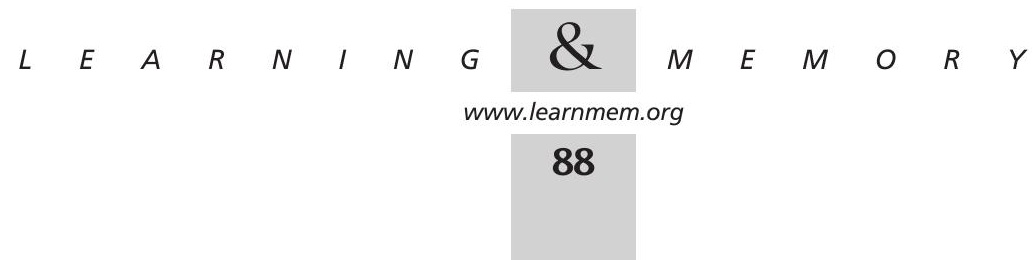



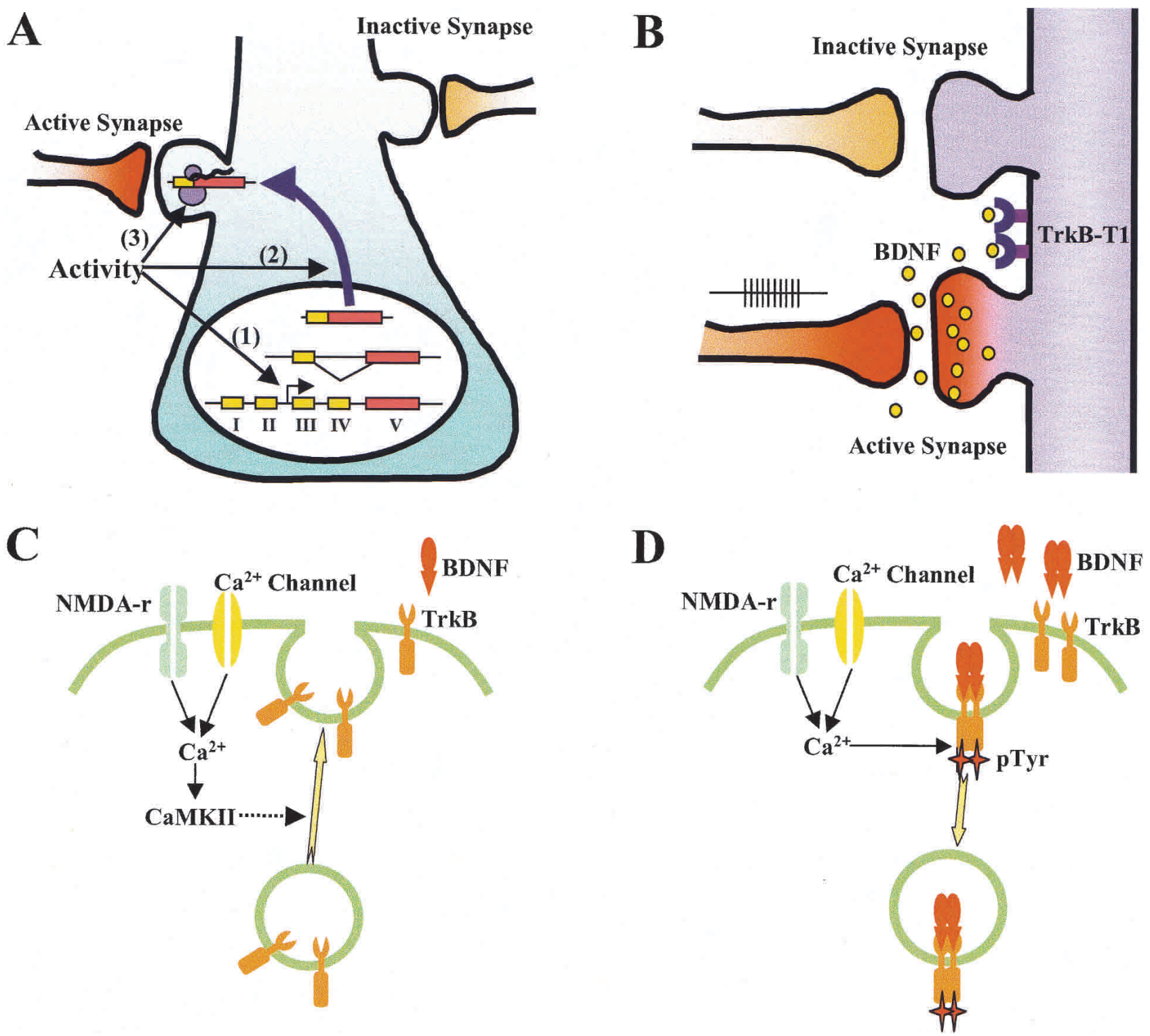

Figure 1 Possible mechanisms to ensure synapse specificity of BDNF modulation. (A) Activity-dependent transcription (1); translocation of mRNA (2); and translation (3). mRNA could be selectively targeted to the active synapse or nonselectively translocated to dendrites, but trapped by an active spine. (B) Activity-dependent secretion. BDNF is secreted locally at or near active synapses and its diffusion is limited by truncated TrkB (TrkB-T1). (C) Activity-dependent insertion of TrkB receptor on cell surface. Neuronal/synaptic activity induces Ca ${ }^{2+}$ influx, leading to fusion of TrkB containing vesicles to the cell membranes. (D) Activity-dependent internalization of TrkB receptor. Activity and Ca ${ }^{2+}$ enhance TrkB receptor tyrosine kinase, which in turn facilitates ligand-induced internalization of TrkB.

Cirelli and Tononi 2000; Berchtold et al. 2001), dietary restriction (Lee et al. 2000), sleep and circadian rhythm (Bova et al. 1998; Liang et al. 1998; Berchtold et al. 1999; Cirelli and Tononi 2000), also appear to affect BDNF gene expression. Moreover, BDNF mRNA levels could be influenced under a variety of pathological conditions known to alter neuronal activity in the brain, including Alzheimer's (Phillips et al. 1991; Narisawa-Saito et al. 1996; Connor et al. 1997; Holsinger et al. 2000), ischemia (Lindvall et al. 1992; Kokaia et al. 1998; Miyake et al. 2002), depression (Kokaia et al. 1993; Kawahara et al. 1997), and stress (Smith et al. 1995; Smith and Cizza 1996; Ueyama et al. 1997).

Timmusk and colleagues discovered that in the rat genomic structures of BDNF, there are four promoters in front of four short 5' exons, all of which are individually spliced onto a common $3^{\prime}$ exon encoding the entire prepro-BDNF protein (Metsis et al. 1993; Timmusk et al. 1993). Exon IV transcript is predominantly expressed in the lung and heart whereas exon I, II, III transcripts are mainly in the brain (Timmusk et al. 1993). These three transcripts exhibit dif-

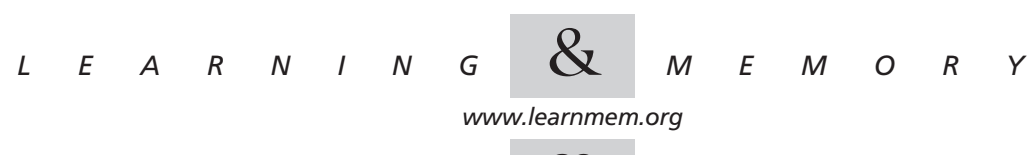


ferential spatial and temporal regulation, and respond differently to kainic acid-induced seizure (Falkenberg et al. 1993; Metsis et al. 1993; Timmusk et al. 1993, 1994a,b; Kokaia et al. 1994). Exon III-containing transcript is by far the most effectively regulated by neuronal activity in the hippocampus and cortex (Metsis et al. 1993; Lauterborn et al. 2000). To analyze the relative importance of the four promoters in vivo, Timmusk et al. generated transgenic mouse lines with individual promoters fused with a reporter gene (Timmusk et al. 1995). They confirmed that different promoters are responsible for tissue-specific distribution of the four transcripts. Moreover, different promoters are used to control lesion-induced BDNF expression in the sciatic nerve, or to upregulate BDNF transcription in neurons by $\mathrm{KCl}$ or kainate. The existence of multiple BDNF promoters may control BDNF gene expression at transcription, mRNA stability, translation, and subcellular distribution levels, and fulfill the different functions of BDNF (such as regulation of neuronal survival, differentiation, synaptic transmission, and plasticity).

At cellular levels, the expression of BDNF mRNA is enhanced when the non-NMDA-type glutamate receptor is activated (Zafra et al. 1990,1991; Lindefors et al. 1992; Lauterborn et al. 2000) and suppressed when GABAa receptor is activated (Lindholm et al. 1994; Berninger et al. 1995). Cholinergic afferent inputs to the cortex and hippocampus also increase the levels of BDNF mRNA (da Penha Berzaghi et al. 1993). An important finding was that the enhancement of BDNF gene expression requires an increase in intracellular calcium concentrations $\left(\left[\mathrm{Ca}^{2+}\right] \mathrm{i}\right.$ ) (Zafra et al. 1992; Ghosh et al. 1994; Sano et al. 1996), possibly by $\mathrm{Ca}^{2+}$ influx through L-type $\mathrm{Ca}^{2+}$ channels or NMDA receptors (Shieh et al. 1998; Tao et al. 1998; Tabuchi et al. 2000). Application of high $\mathrm{K}^{+}$to cultured cortical neurons appears to selectively enhance exon III transcript without affecting those of other exons (Tao et al. 1998). Further characterization identified two elements in the promoter III involved in $\mathrm{Ca}^{2+}$-dependent BDNF expression-the novel $\mathrm{Ca}^{2+}$ responsive sequence 1 (CaRE1, -73 -64 bp) (Tao et al. 2002) and the cAMP responsive element (CRE, -40 -30 bp) (Shieh et al. 1998; Tao et al. 1998). Binding of CRE to CREB, which becomes newly activated by CaM kinase IV-dependent phosphorylation on Ser-133 on $\mathrm{Ca}^{2+}$ influx, is required for depolarization-induced BDNF transcription (Shieh et al. 1998; Tao et al. 1998). The transcription factor that binds to CaRE1, named CaRF, has been cloned recently and shown to be regulated in a $\mathrm{Ca}^{2+}$ - and neuron-specific manner (Tao et al. 2002). Activity-dependent transcription of BDNF gene is therefore mediated by a mechanism that involves cooperation of CREB/CRE and CaRF/CaRE1.

Despite extensive studies, the functional significance of activity-dependent transcription of BDNF gene in synaptic plasticity is still unclear. Although BDNF is considered an immediate-early gene, the kinetics of the induction of BDNF transcription is quite slow (2-4 h) compared with prototype such as c-fos. The slow time course of transcription makes it less likely to mediate most forms of synaptic plasticity including early phase LTP (E-LTP). It offers, however, a mechanism that translates acute changes in synaptic activity to long-lasting alteration of synaptic physiology and morphology. For example, BDNF mRNA expression in the hippocampus is markedly increased $2-4 \mathrm{~h}$ after application of tetanic stimulation (Patterson et al. 1992; Morimoto et al. 1998). This time course correlates well with L-LTP, which is implicated in long-term memory (Abel et al. 1997; Miller et al. 2002; Villarreal et al. 2002; for review, see Kandel 2001). Inhibition of BDNF signaling, either by BDNF gene knockout or by the BDNF scavenger TrkB-IgG, markedly attenuates L-LTP induced by multiple tetani or forskolin exposure (Kang et al. 1997; Korte et al. 1998; Patterson et al. 2001). It is therefore tempting to speculate that the tetanus-induced BDNF expression in the hippocampus mediates LLTP but not E-LTP. One way to test this hypothesis is to create a situation in which activity-dependent BDNF transcription is selectively prohibited while activity-independent BDNF transcription remains intact. This could perhaps be accomplished by generating a "knock-in" mouse line in which the wild-type promoter III is replaced with a mutant one.

Another issue that needs to be addressed is how activity-dependent BDNF transcription contributes to local and synapse-specific modulation. Transcription occurs in the cell body. A homogenous increase of BDNF mRNAs in the cell body may be of some use to regulate neuronal/synaptic activity of a local neuronal network, but this by no means ensures selectivity to any synapses made on the same neuron. One way to overcome this problem is to selectively target BDNF mRNA or protein to the dendrites of activity synapses. Translocation of mRNAs to dendrites for local translation is a new and attractive idea that has been proposed to mediate synapse specificity of hippocampal LTP (Steward and Schuman 2001). BDNF mRNA has been found in the dendrites of hippocampal pyramidal neurons (Dugich-Djordjevic et al. 1992; Wetmore et al. 1994; Crino and Eberwine 1996). An increase in neuronal activity as a consequence of high $\mathrm{K}^{+}$-induced depolarization facilitates the translocation of BDNF mRNA into the dendrites of cultured hippocampal neurons (Tongiorgi et al. 1997), but selective targeting of BDNF mRNA to active synapses has yet to be established. BDNF itself has been shown to induce dendritic targeting of BDNF mRNA (Righi et al. 2000). One must demonstrate, however, that local and activity-dependent secretion of BDNF could recruit BDNF mRNA to the active synapses. An alternative mechanism could be that BDNF mRNA is nonselectively transported to dendritic spines, but is trapped by synapses that undergo high-frequency transmission. This idea is quite similar to the "synaptic tagging" model for the synapse specificity of L-LTP (Frey and Morris

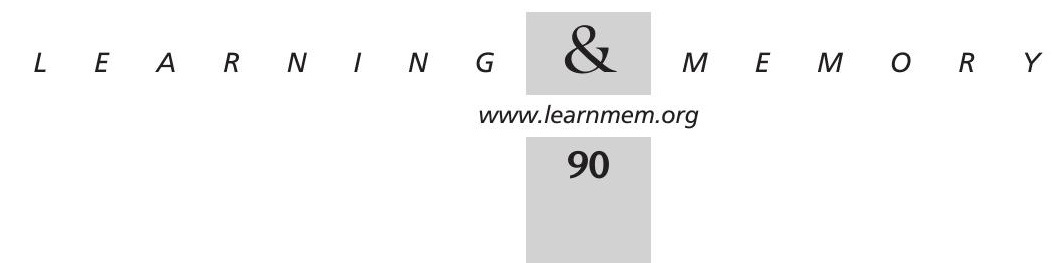


1997). In either dendritic targeting or dendritic trapping model, a key element is the local translation of BDNF mRNA.

\section{Activity-Dependent BDNF Secretion}

Most secretory proteins are initially synthesized from their respective mRNA as precursor proteins in the endoplasmic reticulum (ER) and subsequently translocated to a series of intracellular organelles including the Golgi complex, immature and mature secretory vesicles, and finally secreted into extracellular space (Halban and Irminger 1994). The precursor proteins could be cleaved by two enzymatic pathways, which contribute significantly to how the mature proteins are secreted. Cleavage by furin or furin-like enzymes occurs within the trans-Golgi network (TGN), and prefers the carboxy-terminal side of multibasic sites (Arg-X-Lys/ Arg-Arg) (Hosaka et al. 1991; Dubois et al. 1995). This pathway is used for proteins that are secreted without any trigger (constitutive pathway) (Kelly 1985; Glombik and Gerdes 2000). In excitable cells, such as neurons and neuroendocrine cells, neuropeptides are cleaved by prohormone convertase 1 and 2 (PC1 and PC2) (Rouille et al. 1995). This pathway is used for proteins whose secretion is triggered by certain extracellular and intracellular signals (regulated pathway) (Kelly 1985; Glombik and Gerdes 2000). Neuropeptides are generally secreted through regulated pathway, whereas most growth factors are secreted through constitutive pathway. Neurotrophins are also synthesized in proforms, which could be cleaved by furin as well as PC1 at the same site. The secretion of neurotrophins could be either constitutive or regulated. Non-neuronal cells, such as fibroblasts and Schwann cells, cleave neurotrophins by furin and secrete these proteins constitutively (Bresnahan et al. 1990; Acheson et al. 1991; Seidah et al. 1996a,b). Abundant evidence indicates that neurotrophins can also be cleaved by PC1 (Seidah et al. 1996a; Mowla et al. 1999) and secreted in response to depolarization signals in neurons and neuroendocrine cells (Edwards et al. 1988; Blochl and Thoenen 1995; Blochl and Thoenen 1996; Goodman et al. 1996; Heymach Jr. et al. 1996; Canossa et al. 1997; Kruttgen 1998). It should be pointed out, however, that protease cleavage is not essential for neurotrophin secretion. Small but significant amounts of pro-neurotrophins can be secreted from neurons and the neuroendocrine AtT20 cells (Heymach Jr. et al. 1996; Mowla et al. 1999, 2001; Farhadi et al. 2000; Fahnestock et al. 2001). Hempstead and colleagues recently demonstrated that the proforms of NGF and BDNF can be secreted and cleaved extracellularly by plasmin and a number of metalloproteinases (Lee et al. 2002). Remarkably, they found that pro-NGF binds p75NR with high affinity, leading to p75NR-dependent cell death in cultured neurons, with minimal activation of TrkA. In contrast, the mature NGF prefers TrkA to p75NR, regulating cell survival and neuronal differentiation
(Lee et al. 2002). These results suggest that the function of neurotrophins can be controlled by proteolytic cleavage, and pro- and mature forms of neurotrophins may bind to different receptors, eliciting entirely different biological effects.

Mechanisms underlying regulated secretion of neurotrophins have been studied in some detail. Secretion of neurotrophins transfected into the hippocampal neurons could be induced by a variety of stimuli including depolarization agents high potassium ( $\mathrm{KCl}$ ) and veratridine, excitatory transmitter glutamate, cholinergic agonist carbachol, and neurotrophins themselves (Blochl and Thoenen 1995). Initial experiments suggest a requirement for $\mathrm{Na}^{+}$influx, because replacing $\mathrm{Na}^{+}$with $\mathrm{N}$-methyl-D-glucamine (NMDG) prevented depolarization-induced NGF secretion (Blochl and Thoenen 1995). Subsequent analysis indicated that the secretion of NGF and BDNF is independent of $\mathrm{Na}^{+}$influx, and the NMDG may by itself interfere with NGF secretion (Hoener 2000). Although whether neurotrophin secretion requires the influx of extracellular $\mathrm{Ca}^{2+}$ remains debatable (Goodman et al. 1996; Griesbeck et al. 1999; Hartmann et al. 2001), studies by Thoenen and colleagues strongly suggest that the secretion requires a rise of intracellular $\mathrm{Ca}^{2+}$ ( $\left.\left[\mathrm{Ca}^{2+}\right] \mathrm{i}\right)$ as a consequence of the activation of the IP3 receptors on ER membranes (Canossa et al. 1997; Griesbeck et al. 1999). IP3 is generated by phospholipse C- $\gamma$ (PLC- $\gamma$ ), which is coupled to the neurotrophin receptors Trks and metabotropic glutamate receptors. Thus, activation of PLC- $\gamma$ and the subsequent mobilization of $\mathrm{Ca}^{2+}$ from intracellular $\mathrm{Ca}^{2+}$ stores seem to be the major mechanisms mediating neurotrophin secretion initiated by neurotrophins or neurotransmitter glutamate (Canossa et al. 2001). Using a vaccinia virus expression system, Murphy and colleagues showed that BDNF is sorted into the regulated pathway whereas other neurotrophins are sorted primarily into the constitutive pathway in hippocampal neurons (Mowla et al. 1999; Farhadi et al. 2000). Interestingly, inhibition of furinmediated cleavage shifts pro-NGF and pro-NT3 sorting into the regulated pathway (Mowla et al. 1999; Farhadi et al. 2000). Thus, whether a neurotrophin is directed to constitutive or regulated secretion may depend on the efficiency of furin-cleavage. Furthermore, overexpression of pro-NT3 or formation of NT3-BDNF heterodimer when the two precursors are co-expressed also results in regulated secretion of NT3, suggesting that NT3 could hijack the regulated pathway normally used by BDNF (Mowla et al. 1999; Farhadi et al. 2000).

Two criteria must be met if the secretion of BDNF is involved in activity-dependent and synapse-specific modulation-the secretion of neurotrophins should not only be regulated, but also be local and be controlled by specific patterns of neuronal activity. Data from a number of laboratories have clearly demonstrated that patterned electrical stimulation is far better than simple depolarization by $\mathrm{KCl}$ in

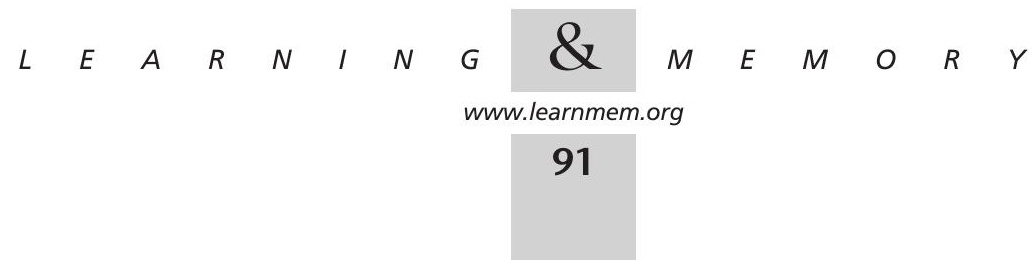


inducing BDNF secretion in several neuronal populations, and the most effective stimulus appears to be the LTP-inducing tetanic stimulation (Balkowiec and Katz 2000; Lever et al. 2001; Gartner and Staiger 2002). It is therefore possible that BDNF is only secreted at sites that fire high-frequency action potentials. BDNF is detected in large, dense core vesicles of sensory neurons and in brain synaptosomes (Fawcett et al. 1997; Michael et al. 1997). Transfection experiments using BDNF-GFP (green fluorescence protein) fusion constructs demonstrate that BDNF is packaged into secretory vesicles that are transported to somatodendritic compartments and, to some extent, to axons (Haubensak et al. 1998; Moller et al. 1998; Kojima et al. 2001a). It is important to note that these BDNF-GFP fluorescence spots are often concentrated at the synaptic junctions, as indicated by co-localization with the presynaptic marker synapsin I and postsynaptic marker PSD95 (Haubensak et al. 1998; Kojima et al. 2001a). The fluorescent spots rapidly disappear in response to depolarization or high frequency stimulation, suggesting secretion of BDNF-GFP from the synaptically localized secretory vesicles (Hartmann et al. 2001; Kojima et al. 2001a). Furthermore, the postsynaptic secretion of BDNF-GFP on high-frequency presynaptic stimulation appears to depend on activation of postsynaptic glutamate receptors (Hartmann et al. 2001). Kojima showed recently that the BDNF-GFP could be induced to secrete at one set of dendritic branches by laser-directed photolysis of caged glutamate, whereas the BDNF-GFP spots in the nearby dendrites of the same neurons were not affected (Kojima et al. 2001b). These results further support the notion that BDNF secretion could be restricted locally to synapses that undergo high-frequency transmission. Secretion of BDNF-GFP from extra-synaptic dendrites, however, has also been observed.

In marked contrast to the experimental support for activity-dependent and perhaps local secretion of BDNF, nothing has been published so far that addresses the functional role of the regulated BDNF secretion. This is very difficult because functional study must be performed in a situation in which the regulated secretion of BDNF is specifically blocked without affecting its constitutive secretion. In a recent collaborative work, we were very fortunate to stumble on a situation just like that (Egan et al. 2003). The human BDNF gene contains one frequent and single nucleotide polymorphism (SNP)-a valine (val) to methionine (met) substitution in the pro region of BDNF protein. Rodent hippocampal neurons transfected with val-BDNF-GFP exhibited a punctate distribution pattern throughout the soma and neuronal processes, whereas those with metBDNF-GFP showed large clusters in the peri-nuclear regions. Moreover, depolarization-induced secretion of metBDNF was reduced significantly, while its constitutive secretion was not changed. In the hippocampus of human subjects with met-BDNF allele, there is a specific reduction in the levels of n-acetyl asparatate (NAA), a putative measure of neuronal integrity and synaptic abundance. Functional magnetic resonance imaging (fMRI) also revealed abnormal hippocampal activation during a memory task in these subjects. In a cohort of 641 subjects, the met/met genotype exhibited a specific impairment in hippocampusdependent episodic memory, while hippocampus-independent cognitive functions were normal. These results represent the first demonstration of a role for BDNF in human hippocampal function, and suggest the importance of activity-dependent secretion of BDNF in learning and memory in vivo.

\section{Activity-Dependent Modulation of BDNF Receptor Trafficking}

An alternative and equally attractive mechanism to constrain BDNF modulation to highly active synapses is the activity-dependent modulation of the responsiveness to BDNF. One way to achieve this is to increase the number of BDNF receptors on the cell surface. Treatment with depolarizing agents results in an increase in the expression of TrkB receptors on the plasma membranes of retinal ganglion cells and spinal neurons (Meyer-Franke et al. 1998). This may explain why BDNF regulation of the survival of retinal ganglion neurons requires depolarization by high $\mathrm{K}^{+}$ or glutamate agonists (Meyer-Franke et al. 1995). Importantly, the increase in surface expression of $\operatorname{TrkB}$ is very rapid and requires no protein synthesis, suggesting an activity-dependent recruitment of the receptor to the plasma membrane by translocation from intracellular stores (MeyerFranke et al. 1998). In the hippocampus, tetanic stimulation, but not simple depolarization or low frequency stimulation, has been shown to facilitate the insertion of TrkB into the cell surface (Du et al. 2000). Immunofluorescence staining suggests that the electric stimulation facilitated the movement of TrkB from the intracellular pool to the cell surface, particularly on neuronal processes. This effect requires $\mathrm{Ca}^{2+}$ influx through NMDA receptors or voltage gated $\mathrm{Ca}^{2+}$ channels and activation of $\mathrm{Ca}^{2+} /$ calmodulin-dependent kinase II (CaMKII), a mechanism quite similar to activitydependent insertion of AMPA type receptors into the postsynaptic membrane during hippocampal LTP (Hayashi et al. 2000). Inhibition of excitatory synaptic transmission blocks the effect of electric stimulation, suggesting that such regulation could occur very locally at active synapses. It seems that the activity-dependent insertion of TrkB receptor is independent of ligand binding (Du et al. 2000). A preferential elevation of TrkB receptor expression at highly active synapses could ensure local action of BDNF without affecting the nearby less active synapses.

Another way to ensure that active neurons/synapses are preferentially regulated by BDNF is the activity-dependent enhancement of the internalization of BDNF-receptor complex. Binding of BDNF to TrkB not only activates its

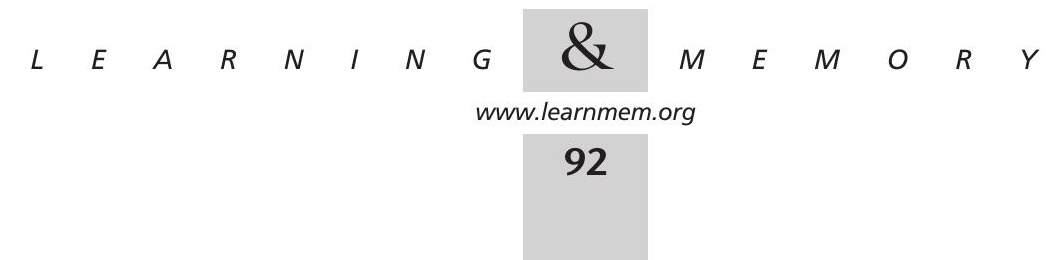


tyrosine kinase and its downstream signaling pathways (Kaplan and Miller 2000; Patapoutian and Reichardt 2001), but also induces the endocytosis of the receptor (Ehlers et al. 1995; Grimes et al. 1996). Internalization of neurotrophin-Trk complex seems to be critical in signal transduction that initiates cell body responses to target-derived neurotrophins (Bhattacharyya et al. 1997; Riccio et al. 1997; Senger and Campenot 1997; Zhang et al. 2000). This is quite unusual because the internalization for most other growth factor receptors is to terminate the signaling process (Sorkin and Waters 1993). The neurotrophin-Trk complex is internalized through clathrin-mediated endocytosis, leading to the formation of a specialized vesicular compartment called signaling endosome (Grimes et al. 1996; Grimes et al. 1997; Beattie et al. 2000). The internalized Trk receptor remains tyrosine-phosphorylated and activated, with its extracellular domain bound to the ligand neurotrophin inside the signaling endosomes, and the intracellular domain tightly associated with a number of signaling molecules such as PLC- $\gamma$, PI3 kinase, and proteins of the Ras-MAP kinase pathway in the cytoplama of the responsive neurons (Grimes et al. 1996; Howe et al. 2001). Using three independent approaches, my laboratory has recently demonstrated that electric stimulation enhances the internalization of TrkB receptor in hippocampal neurons (Du 2001). This activity-dependent modulation of receptor internalization requires $\mathrm{Ca}^{2+}$ influx as well as the tyrosine kinase of the TrkB receptor. Neuronal activity has been shown to rapidly activate TrkB tyrosine kinase, but this was interpreted as a consequence of activity-dependent secretion of BDNF (Aloyz et al. 1999; Binder et al. 1999; Patterson et al. 2001). We found that the same electric stimulation and $\mathrm{Ca}^{2+}$ influx also directly enhances the TrkB kinase in these neurons. Inhibition of internalization had no effect on TrkB kinase, but inhibition of TrkB kinase prevents the modulation of TrkB internalization, suggesting that the activity-dependent receptor endocytosis is mediated by the receptor tyrosine kinase itself. The activity- and $\mathrm{Ca}^{2+}$-dependent modulation of TrkB tyrosine kinase and its internalization provides an alternative and physiologically relevant mechanism by which preferential regulation of active synapses could be achieved. It should be pointed out that the experiments on activity-dependent modulation of neurotrophin responsiveness described above were done in cultured neurons. Their relevance to the BDNF modulation of hippocampal synaptic plasticity in vivo has yet to be established.

\section{Concluding Remarks}

Although the concept of neurotrophic regulation of synaptic function and plasticity is now widely accepted, the underlying mechanisms remain poorly understood. An important but unresolved issue is the relationship between the activity and neurotrophic regulation of synapse development and plasticity. Neurotrophins are diffusible factors, whereas a key feature of synaptic plasticity is that modulation occurs at specific, active synapses. Thus, two questions must be addressed before neurotrophins can truly be regarded as mediators for activity-dependent synaptic plasticity. First, how could neurotrophins distinguish active versus inactive synapses? Second, how could diffusible neurotrophins regulate synaptic efficacy or connectivity in a local and synapse-specific manner? Studies in recent years demonstrated that neuronal activity regulates the transcription of BDNF gene, but this alone is unlikely to ensure synapse specificity attributable to the fact that transcription occurs in neuronal cell body. There is also evidence for activitydependent regulation of the transport of BDNF mRNA into dendrites. Although these studies are promising, selective transport of the mRNA to active synapses has yet to be demonstrated. Furthermore, the significance of target mRNA transport remains unclear unless local translation of BDNF protein at active synapses can be proven. A more acceptable scenario is the activity-dependent local secretion of BDNF protein. Mechanisms for limited diffusion of BDNF protein must be in place to help confine secreted BDNF at synapses that undergo activity-dependent modifications. On the other hand, control of cellular responsiveness to neurotrophins by neuronal activity seems to be at least an equally plausible, if not more applicable, mechanism for neurotrophins to restrict their actions to active synapses. Two strategies have been demonstrated in cultured hippocampal neurons. One is a higher level of expression of the neurotrophin receptors on the cell surface of active neurons/synapses. The other is an activity-dependent control of the internalization of the neurotrophin-receptor complex, leading to an enhanced neurotrophin signaling. It remains to be tested whether these mechanisms actually work in vivo. Although these findings are exciting and promising, we are still in the early stage of understanding the relationship between neuronal activity and neurotrophins in activity-dependent synaptic plasticity. Careful studies should be carried out to elucidate whether these mechanisms are physiologically relevant to the neurotrophic regulation of synaptic plasticity in vivo. Taken together, understanding how neurotrophins could mediate activity-dependent plasticity in a local and synapse-specific manner represents an important direction for future research.

\section{ACKNOWLEDGMENTS}

I thank Drs. Kazuko Sakata, Eugene Zaitsev, and members of my laboratory for helpful discussions and critical comments on the manuscript.

\section{REFERENCES}

Abel, T., Nguyen, P.V., Barad, M., Deuel, T.A., Kandel, E.R., and Bourtchouladze, R. 1997. Genetic demonstration of a role for PKA in the late phase of LTP and in hippocampus-based long-term memory. Cell 88: 615-626.

Acheson, A., Barker, P.A., Alderson, R.F., Miller, F.D., and Murphy, R.A. 1991. Detection of brain-derived neurotrophic factor-like activity in

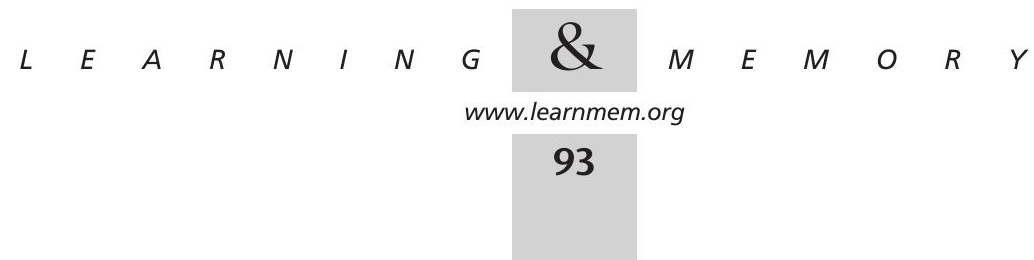


fibroblasts and Schwann cells: Inhibition by antibodies to NGF. Neuron 7: 265-275.

Akaneya, Y., Tsumoto, T., and Hatanaka, H. 1996. Brain-derived neurotrophic factor blocks long-term depression in rat visual cortex. $J$. Neurophysiol. 76: 4198-4201

Akaneya, Y., Tsumoto, T., Kinoshita, S., and Hatanaka, H. 1997. Brain-derived neurotrophic factor enhances long-term potentiation in rat visual cortex. J. Neurosci. 17: 6707-6716.

Aloyz, R., Fawcett, J.P., Kaplan, D.R., Murphy, R.A., and Miller, F.D. 1999. Activity-dependent activation of TrkB neurotrophin receptors in the adult CNS. Learn. Mem. 6: 216-231.

Balkowiec, A. and Katz, D.M. 2000. Activity-dependent release of endogenous brain-derived neurotrophic factor from primary sensory neurons detected by ELISA in situ. J. Neurosci. 20: 7417-7423.

Barbacid, M. 1993. Nerve growth factor: A tale of two receptors. Oncogene 8: 2033-2042.

Beattie, E.C., Howe, C.L., Wilde, A., Brodsky, F.M., and Mobley, W.C. 2000. NGF signals through TrkA to increase clathrin at the plasma membrane and enhance clathrin-mediated membrane trafficking. $J$. Neurosci. 20: 7325-7333

Berchtold, N.C., Oliff, H.S., Isackson, P., and Cotman, C.W. 1999. Hippocampal BDNF mRNA shows a diurnal regulation, primarily in the exon III transcript. Brain Res. Mol. Brain Res. 71: 11-22.

Berchtold, N.C., Kesslak, J.P., Pike, C.J., Adlard, P.A., and Cotman, C.W. 2001. Estrogen and exercise interact to regulate brain-derived neurotrophic factor mRNA and protein expression in the hippocampus. Eur. J. Neurosci. 14: 1992-2002.

Berninger, B. and Poo, M.M. 1996. Fast actions of neurotrophic factors Curr. Opin. Neurobiol. 6: 324-330.

Berninger, B., Marty, S., Zafra, F., da Penha Berzaghi, M., Thoenen, H., and Lindholm, D. 1995. GABAergic stimulation switches from enhancing to repressing BDNF expression in rat hippocampal neurons during maturation in vitro. Development 121: 2327-2335.

Berninger, B., Schinder, A.F., and Poo, M.M. 1999. Synaptic reliability correlates with reduced susceptibility to synaptic potentiation by brain-derived neurotrophic factor. Learn. Mem. 6: 232-242.

Bhattacharyya, A., Watson, F.L., Bradlee, T.A., Pomeroy, S.L., Stiles, C.D. and Segal, R.A. 1997. Trk receptors function as rapid retrograde signal carriers in the adult nervous system. J. Neurosci. 17: 7007-7016.

Biffo, S., Offenhauser, N., Carter, B.D., and Barde, Y.A. 1995. Selective binding and internalisation by truncated receptors restrict the availability of BDNF during development. Development 121: 2461-2470.

Binder, D.K., Routbort, M.J., and McNamara, J.O. 1999. Immunohistochemical evidence of seizure-induced activation of trk receptors in the mossy fiber pathway of adult rat hippocampus. $J$. Neurosci. 19: 4616-4626.

Bliss, T.V.P. and Collingridge, G.L. 1993. A synaptic model of memory: Long-term potentiation in the hippocampus. Nature 361: 31-39.

Blochl, A. and Thoenen, H. 1995. Characterization of nerve growth factor (NGF) release from hippocampal neurons: Evidence for a constitutive and an unconventional sodium-dependent regulated pathway. Eur. J. Neurosci. 7: 1220-1228

-1996. Localization of cellular storage compartments and sites of constitutive and activity-dependent release of nerve growth factor (NGF) in primary cultures of hippocampal neurons. Mol. Cell. Neurosci. 7(3): 173-190.

Bonhoeffer, T. 1996. Neurotrophins and activity-dependent development of the neocortex. Curr. Opin. Neurobiol. 6: 119-126.

Boulanger, L. and Poo, M.M. 1999a. Gating of BDNF-induced synaptic potentiation by cAMP. Science 284: 1982-1984.

. 1999b. Presynaptic depolarization facilitates neurotrophin-induced synaptic potentiation. Nature Neurosci. 2: 346-351.

Bova, R., Micheli, M.R., Qualadrucci, P., and Zucconi, G.G. 1998. BDNF and trkB mRNAs oscillate in rat brain during the light-dark cycle. Brain Res. Mol. Brain Res. 57: 321-324.

Bozzi, Y., Pizzorusso, T., Cremisi, F., Rossi, F.M., Barsacchi, G., and Maffei, L. 1995. Monocular deprivation decreases the expression of messenger
RNA for brain-derived neurotrophic factor in the rat visual cortex Neuroscience 69: 1133-1144.

Bresnahan, P.A., Leduc, R., Thomas, L., Thorner, J., Gibson, H.L., Brake, A.J., Barr, P.J., and Thomas, G. 1990. Human fur gene encodes a yeast KEX2-like endoprotease that cleaves pro- $\beta-\mathrm{NGF}$ in vivo. J. Cell Biol. 111: 2851-2859.

Cabelli, R.J., A. Horn, and C.J. Shatz. 1995. Inhibition of ocular dominance column formation by infusion of NT-4/5 or BDNF. Science 267: 1662-1666

Canossa, M., Griesbeck, O., Berninger, B., Campana, G., Kolbeck, R., and Thoenen, H. 1997. Neurotrophin release by neurotrophins: Implications for activity-dependent neuronal plasticity. Proc. Natl. Acad. Sci. 94: 13279-13286.

Canossa, M., Gartner, A., Campana, G., Inagaki, N., and Thoenen, H. 2001 Regulated secretion of neurotrophins by metabotropic glutamate group I (mGluRI) and Trk receptor activation is mediated via phospholipase C signalling pathways. EMBO J. 20: 1640-1650.

Castren, E., Zafra, F., Thoenen, H., and Lindholm, D. 1992. Light regulates expression of brain-derived neurotrophic factor mRNA in the rat visua cortex. Proc. Natl. Acad. Sci. 89: 9444-9448.

Castren, E., Pitkanen, M., Sirvio, J., Parsadanian, A., Lindholm, D., Thoenen, H., and J. Riekkinen, P. 1993. The induction of LTP increases BDNF and NGF mRNA but decreases NT-3 mRNA in the dentate gyrus. Neuroreport 4: 895-898.

Chang, S. and Popov, S.V. 1999. Long-range signaling within growing neurites mediated by neurotrophin-3. Proc. Natl. Acad. Sci. 96: 4095-4100

Chao, M.V. 1992. Neurotrophin receptors: A window into neuronal differentiation. Neuron 9: 583-593.

Cirelli, C. and Tononi, G. 2000. Differential expression of plasticity-related genes in waking and sleep and their regulation by the noradrenergic system. J. Neurosci. 20: 9187-9194.

Cohen-Cory, S. and Fraser, S.E. 1995. Effects of brain-derived neurotrophic factor on optic axon branching and remodelling in vivo. Nature 378: 192-196.

Connor, B., Young, D., Yan, Q., Faull, R.L., Synek, B., and Dragunow, M. 1997. Brain-derived neurotrophic factor is reduced in Alzheimer's disease. Brain Res. Mol. Brain Res. 49: 71-81.

Crino, P.B. and Eberwine, J. 1996. Molecular characterization of the dendritic growth cone: Regulated mRNA transport and local protein synthesis. Neuron 17: 1173-1187.

da Penha Berzaghi, M., Cooper, J., Castren, E., Zafra, F., Sofroniew, M., Thoenen, H., and Lindholm, D. 1993. Cholinergic regulation of brain-derived neurotrophic factor (BDNF) and nerve growth factor (NGF) but not neurotrophin-3 (NT-3) mRNA levels in the developing rat hippocampus. J. Neurosci. 13: 3818-3126.

Dragunow, M., Beilharz, E., Mason, B., Lawlor, P., Abraham, W., and Gluckman, P. 1993. Brain-derived neurotrophic factor expression after long-term potentiation. Neurosci. Lett. 160: 232-236.

Du, J., Feng, L., Yang, F., and Lu, B. 2000. Activity- and Ca(2+)-dependent modulation of surface expression of brain-derived neurotrophic factor receptors in hippocampal neurons. J. Cell Biol. 150: 1423-1434.

Du, J., Feng, L., and Lu, B. 2001. Activity- and tyrosine kinase-dependent facilitation of TrkB receptor internalization in hippocampal neurons Soc. Neurosci. Abst. 27: 801-813

Dubois, C.M., Laprise, M.H., Blanchette, F., Gentry, L.E., and Leduc, R. 1995. Processing of transforming growth factor $\beta 1$ precursor by human furin convertase. J. Biol. Chem. 270: 10618-10624.

Dugich-Djordjevic, M.M., Tocco, G., Willoughby, D.A., Najm, I., Pasinetti, G., Thompson, R., Baudry, M., and Hefti, F. 1992. BDNF mRNA expression in the developing rat brain following kainic acid-induced seizure activity. Neuron 8: 1127-1138.

Edwards, R.H., Selby, M.J., Mobley, W.C., Weinrich, S.L., Hruby, D.E., and Rutter, W.J. 1988. Processing and secretion of nerve growth factor: Expression in mammalian cells with a vaccinia virus vector. $\mathrm{Mol}$. Cell Biol. 8: 2456-2464

Egan, M.F., Kojima, M., Callicott, J.H., Goldberg, T.E., Kolachana, B.S Zaistev, E., Bertolino, A., Gold, B., Goldman, D., Dean, M., et al. 2003.

\section{$L \begin{array}{llllllllllllll}L & A & R & N & I & N & G & \& & M & E & M & O & R & Y\end{array}$}


A single nucleotide polymorphism in BDNF gene affects regulated secretion of BDNF and human memory and hippocampal function. Cell (in press).

Ehlers, M.D., Kaplan, D.R., Price, D.L., and Koliatsos, V.E. 1995. NGF-stimulated retrograde transport of trkA in the mammalian nervous system. J. Cell Biol. 130: 149-156.

Ernfors, P., Bengzon, J., Kokaia, Z., Persson, H., and Lindvall, O. 1991. Increased levels of messenger RNAs for neurotrophic factors in the brain during kindling epileptogenesis. Neuron 7: 165-176.

Fahnestock, M., Michalski, B., Xu, B., and Coughlin, M.D. 2001. The precursor pro-nerve growth factor is the predominant form of nerve growth factor in brain and is increased in Alzheimer's disease. Mol. Cell. Neurosci. 18: 210-220.

Falkenberg, T., Mohammed, A.K., Henriksson, B., Persson, H., Winblad, B., and Lindefors, N. 1992. Increased expression of brain-derived neurotrophic factor mRNA in rat hippocampus is associated with improved spatial memory and enriched environment. Neurosci. Lett. 138: 153-156.

Falkenberg, T., Metsis, M., Timmusk, T., and Lindefors, N. 1993. Entorhinal cortex regulation of multiple brain-derived neurotrophic factor promoters in the rat hippocampus. Neuroscience 57: 891-896.

Farhadi, H.F., Mowla, S.J., Petrecca, K., Morris, S.J., Seidah, N.G., and Murphy, R.A. 2000. Neurotrophin-3 sorts to the constitutive secretory pathway of hippocampal neurons and is diverted to the regulated secretory pathway by coexpression with brain-derived neurotrophic factor. J. Neurosci. 20: 4059-4068.

Fawcett, J.P., Aloyz, R., McLean, J.H., Pareek, S., Miller, F.D., McPherson, P.S., and Murphy, R.A. 1997. Detection of brain-derived neurotrophic factor in a vesicular fraction of brain synaptosomes. J. Biol. Chem. 272: 8837-8840.

Figurov, A., Pozzo-Miller, L., Olafsson, P., Wang, T., and Lu, B. 1996. Regulation of synaptic responses to high-frequency stimulation and LTP by neurotrophins in the hippocampus. Nature 381: 706-709.

Frey, U. and Morris, R.G. 1997. Synaptic tagging and long-term potentiation. Nature 385: 533-536.

Fryer, R.H., Kaplan, D.R., Feinstein, S.C., Radeke, M.J., Grayson, D.R., and Kromer, L.F. 1996. Developmental and mature expression of full-length and truncated TrkB receptors in the rat forebrain. J. Comp. Neurol. 374: 21-40.

Gartner, A. and Staiger, V. 2002. Neurotrophin secretion from hippocampal neurons evoked by long-term-potentiation-inducing electrical stimulation patterns. Proc. Natl. Acad. Sci. 99: 6386-6391.

Ghosh, A., Carnahan, J., and Greenberg, M.E. 1994. Requirement for BDNF in activity-dependent survival of cortical neurons. Science 263: 1618-1623.

Glombik, M.M. and Gerdes, H.H. 2000. Signal-mediated sorting of neuropeptides and prohormones: Secretory granule biogenesis revisited. Biochimie 82: 315-326.

Gonzalez, M., Ruggiero, F.P., Chang, Q., Shi, Y.J., Rich, M.M., Kraner, S., and Balice-Gordon, R.J. 1999. Disruption of TrkB-mediated signaling induces disassembly of postsynaptic receptor clusters at neuromuscular junctions. Neuron 24: 567-583.

Goodman, L.J., Valverde, J., Lim, F., Geschwind, M.D., Federoff, H.J., Geller, A.I., and Hefti, F. 1996. Regulated release and polarized localization of brain-derived neurotrophic factor in hippocampal neurons. Mol. Cell. Neurosci. 7: 223-228.

Gottschalk, W., Pozzo-Miller, L.D., Figurov, A., and Lu, B. 1998. Presynaptic modulation of synaptic transmission and plasticity by brain-derived neurotrophic factor in the developing hippocampus. $J$. Neurosci. 18: 6830-6839.

Gottschalk, W.A., Jiang, H., Tartaglia, N., Feng, L., Figurov, A., and Lu, B. 1999. Signaling mechanisms mediating BDNF modulation of synaptic plasticity in the hippocampus. Learn. Mem. 6: 243-256.

Griesbeck, O., Canossa, M., Campana, G., Gartner, A., Hoener, M.C., Nawa, H., Kolbeck, R., and Thoenen, H. 1999. Are there differences between the secretion characteristics of NGF and BDNF? Implications for the modulatory role of neurotrophins in activity-dependent neuronal plasticity. Microsc. Res. Tech. 45: 262-275.
Grimes, M.L., Zhou, J., Beattie, E.C., Yuen, E.C., Hall, D.E., Valletta, J.S., Topp, K.S., LaVail, J.H., Bunnett, N.W., and Mobley, W.C. 1996. Endocytosis of activated TrkA: Evidence that nerve growth factor induces formation of signaling endosomes. J. Neurosci. 16: 7950-7964

Grimes, M.L., Beattie, E., and Mobley, W.C. 1997. A signaling organelle containing the nerve growth factor-activated receptor tyrosine kinase, TrkA. Proc. Natl. Acad. Sci. 94: 9909-9914.

Halban, P.A. and Irminger, J.C. 1994. Sorting and processing of secretory proteins. Biochem. J. 299: 1-18.

Hall, J., Thomas, K.L., and Everitt, B.J. 2000. Rapid and selective induction of BDNF expression in the hippocampus during contextual learning. Nature Neurosci. 3: 533-535.

Hartmann, M., Heumann, R., and Lessmann, V. 2001. Synaptic secretion of BDNF after high-frequency stimulation of glutamatergic synapses. EMBO J. 20: 5887-5897.

Haubensak, W., Narz, F., Heumann, R., and Lessmann, V. 1998. BDNF-GFP containing secretory granules are localized in the vicinity of synaptic junctions of cultured cortical neurons. J. Cell Sci. 111: 1483-1493.

Hayashi, Y., Shi, S.H., Esteban, J.A., Piccini, A., Poncer, J.C., and Malinow, R. 2000. Driving AMPA receptors into synapses by LTP and CaMKII: Requirement for GluR1 and PDZ domain interaction. Science 287: 2262-2267.

He, X., Yang, F., Xie, Z., and Lu, B. 2000. Intracellular $\mathrm{Ca}^{2+}$ and $\mathrm{Ca}^{2+} /$ Calmodulin-dependent kinase II mediate acute potentiation of neurotransmitter release by neurotrophin-3. J. Cell Biol. 149: 783-792.

Heymach Jr., J.V., Kruttgen, A., Suter, U., and Shooter, E.M. 1996. The regulated secretion and vectorial targeting of neurotrophins in neuroendocrine and epithelial cells. J. Biol. Chem. 271: 25430-25437.

Hoener, M.C. 2000. Role played by sodium in activity-dependent secretion of neurotrophins-revisited. Eur. J. Neurosci. 12: 3096-3106.

Holsinger, R.M., Schnarr, J., Henry, P., Castelo, V.T., and Fahnestock, M. 2000. Quantitation of BDNF mRNA in human parietal cortex by competitive reverse transcription-polymerase chain reaction: Decreased levels in Alzheimer's disease. Brain Res. Mol. Brain Res. 76: 347-354

Hosaka, M., Nagahama, M., Kim, W.S., Watanabe, T., Hatsuzawa, K., Ikemizu, J., Murakami, K., and Nakayama, K. 1991. Arg-X-Lys/Arg-Arg motif as a signal for precursor cleavage catalyzed by furin within the constitutive secretory pathway. J. Biol. Chem. 266: 12127-12130.

Howe, C.L., Valletta, J.S., Rusnak, A.S., and Mobley, W.C. 2001. NGF Signaling from clathrin-coated vesicles. Evidence that signaling endosomes serve as a platform for the Ras-MAPK pathway. Neuron 32: $801-814$

Huang, E.J. and Reichardt, L.F. 2001. Neurotrophins: Roles in neuronal development and function. Ann. Rev. Neurosci. 24: 677-736.

Huang, Z.J., Kirkwood, A., Pizzorusso, T., Porciatti, V., Morales, B., Bear, M.F., Maffei, L., and Tonegawa, S. 1999. BDNF regulates the maturation of inhibition and the critical period of plasticity in mouse visual cortex. Cell 98: 739-755.

Huber, K.M., Sawtell, N.B., and Bear, M.F. 1998. Brain-derived neurotrophic factor alters the synaptic modification threshold in visual cortex. Neuropharmacology 37: 571-579.

Ickes, B.R., Pham, T.M., Sanders, L.A., Albeck, D.S., Mohammed, A.H., and Granholm, A.C. 2000. Long-term environmental enrichment leads to regional increases in neurotrophin levels in rat brain. Exp. Neurol. 164: 45-52.

Isackson, P.J., Huntsman, M.M., Murray, K.D., and Gall, C.M. 1991. BDNF mRNA expression is increased in adult rat forebrain after limbic seizures: Temporal patterns of induction distinct from NGF. Neuron 6: 937-948.

Jiang, B., Akaneya, Y., Ohshima M., Ichisaka, S., Hata, Y., and Tsumoto, T. 2001. Brain-derived neurotrophic factor induces long-lasting potentiation of synaptic transmission in visual cortex in vivo in young rats, but not in the adult. Eur. J. Neurosci. 14: 1219-1228.

Jovanovic, J.N., Czernik, A.J., Fienberg, A.A., Greengard, P., and Sihra, T.S. 2000. Synapsins as mediators of BDNF-enhanced neurotransmitter release. Nature Neurosci. 3: 323-329.

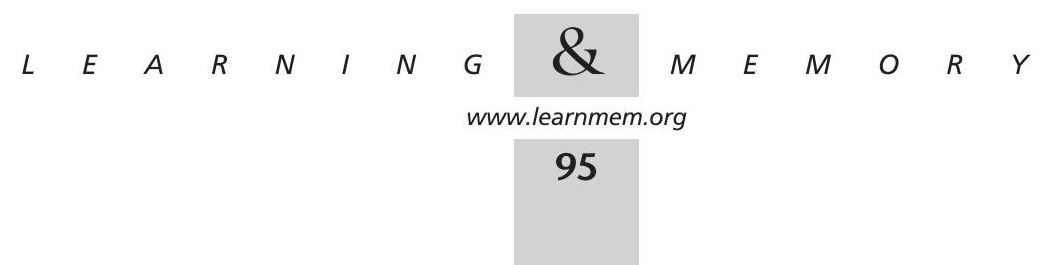


Kandel, E.R. 2001. The molecular biology of memory storage: A dialogue between genes and synapses. Science 294: 1030-1038.

Kang, H., Welcher, A.A., Shelton, D., and Schuman, E.M. 1997. Neurotrophins and time: Different roles for TrkB signaling in hippocampal long-term potentiation. Neuron 19: 653-664.

Kaplan, D.R. and Miller, F.D. 2000. Neurotrophin signal transduction in the nervous system. Curr. Opin. Neurobiol. 10: 381-391.

Katz, L.C. and Shatz, C.J. 1996. Synaptic activity and the construction of cortical circuits. Science 274: 1133-1138.

Kawahara, N., Croll, S.D., Wiegand, S.J., and Klatzo, I. 1997. Cortical spreading depression induces long-term alterations of BDNF levels in cortex and hippocampus distinct from lesion effects: Implications for ischemic tolerance. Neurosci. Res. 29: 37-47.

Kelly, R.B. 1985. Pathways of protein secretion in eukaryotes. Science 230: $25-32$

Kesslak, J.P., So, V., Choi, J., Cotman, C.W., and Gomez-Pinilla, F. 1998. Learning upregulates brain-derived neurotrophic factor messenger ribonucleic acid: A mechanism to facilitate encoding and circuit maintenance? Behav. Neurosci. 112: 1012-1019.

Kinoshita, S., Yasuda, H., Taniguchi, N., Katoh-Semba, R., Hatanaka, H. and Tsumoto, T. 1999. Brain-derived neurotrophic factor prevents low-frequency inputs from inducing long-term depression in the developing visual cortex. J. Neurosci. 19: 2122-2130.

Kojima, M., Takei, N., Numakawa, T., Ishikawa, Y., Suzuki, S., Matsumoto, T., Katoh-Semba, R., Nawa, H., and Hatanaka, H. 2001a. Biological characterization and optical imaging of brain-derived neurotrophic factor-green fluorescent protein suggest an activity-dependent local release of brain-derived neurotrophic factor in neurites of cultured hippocampal neurons. J. Neurosci. Res. 64: 1-10.

Kojima, M., Taguchi, T., Ohmiva, Y., and Hatanaka, H. 2001b. Activity-dependent local release of BDNF from postsynaptic neurons Soc. Neurosci. Abst. 27: 801-816.

Kokaia, Z., Gido, G., Ringstedt, T., Bengzon, J., Kokaia, M., Siesjo, B.K., Persson, H., and Lindvall, O. 1993. Rapid increase of BDNF mRNA levels in cortical neurons following spreading depression: Regulation by glutamatergic mechanisms independent of seizure activity. Brain Res. Mol. Brain Res. 19: 277-286.

Kokaia, Z., Metsis, M., Kokaia, M., Bengzon, J., Elmer, E., Smith, M.L., Timmusk, T., Siesjo, B.K., Persson, H., and Lindvall, O. 1994. Brain insults in rats induce increased expression of the BDNF gene through differential use of multiple promoters. Eur. J. Neurosci. 6: 587-596.

Kokaia, Z., Andsberg, G., Yan, Q., and Lindvall, O. 1998. Rapid alterations of BDNF protein levels in the rat brain after focal ischemia: Evidence for increased synthesis and anterograde axonal transport. Exp. Neurol. 154: 289-301.

Korte, M., Carroll, P., Wolf, E., Brem, G., Thoenen, H., and Bonhoeffer, T. 1995. Hippocampal long-term potentiation is impaired in mice lacking brain-derived neurotrophic factor. Proc. Natl. Acad. Sci. 92: 8856-8860

Korte, M., Kang, H., Bonhoeffer, T., and Schuman, E. 1998. A role for BDNF in the late-phase of hippocampal long-term potentiation. Neuropharmacology 37: 553-559.

Kovalchuk, Y., Hanse, E., Kafitz, K.W., and Konnerth, A. 2002 Postsynaptic induction of BDNF-mediated long-term potentiation. Science 295: 1729-1734.

Kruttgen, A., Moller, J.C., Heymach Jr., J.V., Shooter, E.M. 1998. Neurotrophins induce release of neurotrophins by the regulated secretory pathway. Proc. Natl. Acad. Sci. USA 95: 9614-9619.

Kumura, E., Kimura, F., Taniguchi, N., and Tsumoto, T. 2000. Brain-derived neurotrophic factor blocks long-term depression in solitary neurones cultured from rat visual cortex. J. Physiol. 524: 195-204.

Lauterborn, J.C., Lynch, G., Vanderklish, P., Arai, A., and Gall, C.M. 2000 Positive modulation of AMPA receptors increases neurotrophin expression by hippocampal and cortical neurons. J. Neurosci. 20: $8-21$

Lee, J., Duan, W., Long, J.M., Ingram, D.K., and Mattson, M.P. 2000. Dietary restriction increases the number of newly generated neural cells, and induces BDNF expression, in the dentate gyrus of rats. $J$ Mol. Neurosci. 15: 99-108.

Lee, R., Kermani, P., Teng, K.K., and Hempstead, B.L. 2002. Regulation of cell survival by secreted proneurotrophins. Science 294: 1945-1948.

Lein, E.S. and Shatz, C.J. 2000. Rapid regulation of brain-derived neurotrophic factor mRNA within eye-specific circuits during ocular dominance column formation. J. Neurosci. 20: 1470-1483.

Lessmann, V. and Heumann, R. 1998. Modulation of unitary glutamatergic synapses by neurotrophin- $4 / 5$ or brain-derived neurotrophic factor in hippocampal microcultures: Presynaptic enhancement depends on pre-established paired-pulse facilitation. Neuroscience 86: 399-413

Lever, I.J., Bradbury, E.J., Cunningham, J.R., Adelson, D.W., Jones, M.G., McMahon, S.B., Marvizon, J.C., and Malcangio, M. 2001. Brain-derived neurotrophic factor is released in the dorsal horn by distinctive patterns of afferent fiber stimulation. J. Neurosci. 21: 4469-4477.

Levi-Montalcini, R. 1987. The nerve growth factor: Thirty-five years later. Biosci. Rep. 7: 681-699.

Levine, E.S., Crozier, R.A., Black, I.B., and Plummer, M.R. 1998. Brain-derived neurotrophic factor modulates hippocampal synaptic transmission by increasing $\mathrm{N}$-methyl-D-aspartic acid receptor activity. Proc. Natl. Acad. Sci. 95: 10235-10239.

Lewin, G.R. and Barde, Y.-A. 1996. Physiology of the neurotrophins. Annu. Rev. Neurosci. 19: 289-317.

Liang, F.Q., Walline, R., and Earnest, D.J. 1998. Circadian rhythm of brain-derived neurotrophic factor in the rat suprachiasmatic nucleus. Neurosci. Lett. 242: 89-92.

Lindefors, N., Ballarin, M., Ernfors, P., Falkenberg, T., and Persson, H. 1992. Stimulation of glutamate receptors increases expression of brain-derived neurotrophic factor mRNA in rat hippocampus. Ann. N.Y. Acad. Sci. 648: 296-299.

Linden, D.J. 1994. Long-term synaptic depression in the mammalian brain. Neuron 12: 457-472

Lindholm, D., Castren, E., Berzaghi, M., Blochl, A., and Thoenen, H. 1994. Activity-dependent and hormonal regulation of neurotrophin mRNA levels in the brain-implications for neuronal plasticity. J. Neurobiol. 25: $1362-1372$

Lindvall, O., Ernfors, P., Bengzon, J., Kokaia, Z., Smith, M.L., Siesjo, B.K., and Persson, H. 1992. Differential regulation of mRNAs for nerve growth factor, brain-derived neurotrophic factor, and neurotrophin 3 in the adult rat brain following cerebral ischemia and hypoglycemic coma. Proc. Natl. Acad. Sci. 89: 648-662.

Liou, J.C. and Fu, W.M. 1997. Regulation of quantal secretion from developing motoneurons by postsynaptic activity-dependent release of NT-3. J. Neurosci. 17: 2459-2468.

Lohof, A.M., Ip, N.Y., and Poo, M.M. 1993. Potentiation of developing neuromuscular synapses by the neurotrophins NT-3 and BDNF. Nature 363: 350-353.

Lu, B. and Chow, A. 1999. Neurotrophins and hippocampal synaptic plasticity. J. Neurosci. Res. 58: 76-87.

Lu, B. and Figurov, A. 1997. Role of neurotrophins in synapse development and plasticity. Rev. Neurosci. 8: 1-12.

Maffei, L., Berardi, N., Domenici, L., Parisi, V., and Pizzorusso, T. 1992 Nerve growth factor (NGF) prevents the shift in ocular dominance distribution of visual cortical neurons in monocularly deprived rats. $J$. Neurosci. 12: 4651-4662.

Malenka, R.C. and Nicoll, R.A. 1999. Long-term potentiation-a decade of progress? Science 285: 1870-1874

McAllister, A.K., Lo, D.C., and Katz, L.C. 1995. Neurotrophins regulate dendritic growth in developing visual cortex. Neuron 15: 791-803.

McAllister, A.K., Katz, L.C., and Lo, D.C. 1996. Neurotrophin regulation of cortical dendritic growth requires activity. Neuron 17: 1057-1064.

McAllister, A.K., Katz, L.C., and Lo, D.C. 1999. Neurotrophins and synaptic plasticity. Annu. Rev. Neurosci. 22: 295-318.

McEwen, B.S. 1999. Stress and hippocampal plasticity. Annu. Rev. Neurosci. 22: 105-122

Metsis, M., Timmusk, T., Arenas, E., and Persson, H. 1993. Differential usage of multiple brain-derived neurotrophic factor promoters in the

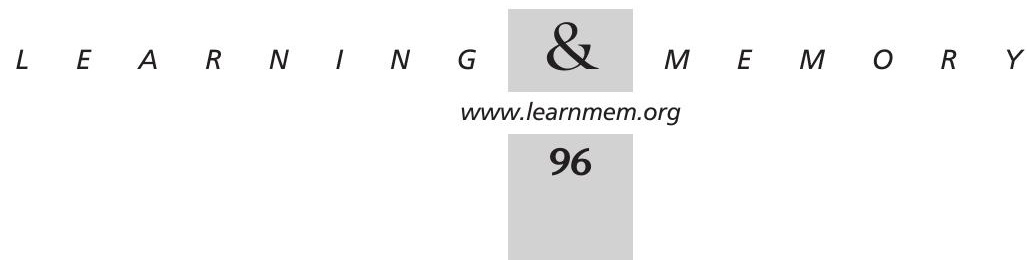


rat brain following neuronal activation. Proc. Natl. Acad. Sci. 90: 8802-8806

Meyer-Franke, A., Kaplan, M.R., Pfrieger, F.W., and Barres, B.A. 1995 Characterization of the signaling interactions that promote the survival and growth of developing retinal ganglion cells in culture. Neuron 15: 805-819.

Meyer-Franke, A., Wilkinson, G.A., Kruttgen, A., Hu, M., Munro, E., Hanson Jr., M.G., Reichardt, L.F., and Barres, B.A. 1998. Depolarization and cAMP elevation rapidly recruit TrkB to the plasma membrane of CNS neurons. Neuron 21: 681-693.

Michael, G.J., Averill, S., Nitkunan, A., Rattray, M., Bennett, D.L., Yan, Q., and Priestley, J.V. 1997. Nerve growth factor treatment increases brain-derived neurotrophic factor selectively in TrkA-expressing dorsal root ganglion cells and in their central terminations within the spinal cord. J. Neurosci. 17: 8476-8490.

Miller, S., Yasuda, M., Coats, J.K., Jones, Y., Martone, M.E., and Mayford, M. 2002. Disruption of dendritic translation of CaMKII $\alpha$ impairs stabilization of synaptic plasticity and memory consolidation. Neuron 36: 507-519.

Miyake, K., Yamamoto, W., Tadokoro, M., Takagi, N., Sasakawa, K., Nitta, A., Furukawa, S., and Takeo, S. 2002. Alterations in hippocampal GAP-43, BDNF, and L1 following sustained cerebral ischemia. Brain Res. 935: 24-31.

Mizuno, M., Yamada, K., Olariu, A., Nawa, H., and Nabeshima, T. 2000. Involvement of brain-derived neurotrophic factor in spatial memory formation and maintenance in a radial arm maze test in rats. $J$. Neurosci. 20: 7116-7121.

Moller, J.C., Kruttgen, A., Heymach Jr., J.V., Ghori, N., and Shooter, E.M 1998. Subcellular localization of epitope-tagged neurotrophins in neuroendocrine cells. J. Neurosci. Res. 51: 463-472.

Morimoto, K., Sato, K., Sato, S., Yamada, N., and Hayabara, T. 1998. Time-dependent changes in neurotrophic factor mRNA expression after kindling and long-term potentiation in rats. Brain Res. Bull. 45: 599-605.

Mowla, S.J., Pareek, S., Farhadi, H.F., Petrecca, K., Fawcett, J.P., Seidah, N.G., Morris, S.J., Sossin, W.S., and Murphy, R.A. 1999. Differential sorting of nerve growth factor and brain-derived neurotrophic factor in hippocampal neurons. J. Neurosci. 19: 2069-2080.

Mowla, S.J., Farhadi, H.F., Pareek, S., Atwal, J.K., Morris, S.J., Seidah, N.G., and Murphy, R.A. 2001. Biosynthesis and post-translational processing of the precursor to brain-derived neurotrophic factor. J. Biol. Chem. 276: 12660-12666

Nanda, S.A. and Mack, K.J. 2000. Seizures and sensory stimulation result in different patterns of brain derived neurotrophic factor protein expression in the barrel cortex and hippocampus. Brain Res. Mol. Brain Res. 78: 1-14.

Narisawa-Saito, M., Wakabayashi, K., Tsuji, S., Takahashi, H., and Nawa, H. 1996. Regional specificity of alterations in NGF, BDNF and NT-3 levels in Alzheimer's disease. Neuroreport 7: 2925-2928

Neeper, S.A., Gomez-Pinilla, F., Choi, J., and Cotman, C.W. 1996. Physical activity increases mRNA for brain-derived neurotrophic factor and nerve growth factor in rat brain. Brain Res. 726: 49-56.

Nick, T.A. and Ribera, A.B. 2000. Synaptic activity modulates presynaptic excitability. Nature Neurosci. 3: 142-149.

Oliff, H.S., Berchtold, N.C., Isackson, P., and Cotman, C.W. 1998 Exercise-induced regulation of brain-derived neurotrophic factor (BDNF) transcripts in the rat hippocampus. Brain Res. Mol. Brain Res. 61: $147-153$.

Patapoutian, A. and Reichardt, L.F. 2001. Trk receptors: Mediators of neurotrophin action. Curr. Opin. Neurobiol. 11: 272-280.

Patterson, S., Grover, L.M., Schwartzkroin, P.A., and Bothwell, M. 1992 Neurotrophin expression in rat hippocampal slices: A stimulus paradigm inducing LTP in CA1 evokes increases in BDNF and NT-3 mRNAs. Neuron 9: 1081-1088.

Patterson, S.L., Abel, T., Deuel, T.A., Martin, K.C., Rose, J.C., and Kandel, E.R. 1996. Recombinant BDNF rescues deficits in basal synaptic transmission and hippocampal LTP in BDNF knockout mice. Neuron 16: $1137-1145$
Patterson, S.L., Pittenger, C., Morozov, A., Martin, K.C., Scanlin, H., Drake, C., and Kandel, E.R. 2001. Some forms of cAMP-mediated long-lasting potentiation are associated with release of BDNF and nuclear translocation of phospho-MAP kinase. Neuron 32: 123-140.

Phillips, H.S., Hains, J.M., Armanini, M., Laramee, G.R., Johnson, S.A., and Winslow, J.W. 1991. BDNF mRNA is decreased in the hippocampus of individuals with Alzheimer's disease. Neuron 7: 695-702.

Pollock, G.S., Vernon, E., Forbes, M.E., Yan, Q., Ma, Y.T., Hsieh, T., Robichon, R., Frost, D.O., and Johnson, J.E. 2001. Effects of early visual experience and diurnal rhythms on BDNF mRNA and protein levels in the visual system, hippocampus, and cerebellum. J. Neurosci. 21: 3923-3931.

Poo, M.M. 2001. Neurotrophins as synaptic modulators. Nature Rev Neurosci. 2: 24-32.

Pozzo-Miller, L., Gottschalk, W.A., Zhang, L., McDermott, K., Du, J., Gopalakrishnan, R., Oho, C., Shen, Z., and Lu, B. 1999. Impairments in high frequency transmission, synaptic vesicle docking and synaptic protein distribution in the hippocampus of BDNF knockout mice. $J$. Neurosci. 19: 4972-4983.

Riccio, A., Pierchala, B.A., Ciarallo, C.L., and Ginty, D.D. 1997. An NGF-TrkA-mediated retrograde signal to transcription factor CREB in sympathetic neurons. Science 277: 1097-1100.

Righi, M., Tongiorgi, E., and Cattaneo, A. 2000. Brain-derived neurotrophic factor (BDNF) induces dendritic targeting of BDNF and tyrosine kinase B mRNAs in hippocampal neurons through a phosphatidylinositol-3 kinase-dependent pathway. J. Neurosci. 20: 3165-3174.

Rocamora, N., Welker, E., Pascual, M., and Soriano, E. 1996. Upregulation of BDNF mRNA expression in the barrel cortex of adult mice after sensory stimulation. J. Neurosci. 16: 4411-4419.

Rossi, F.M., Bozzi, Y., Pizzorusso, T., and Maffei, L. 1999. Monocular deprivation decreases brain-derived neurotrophic factor immunoreactivity in the rat visual cortex. Neuroscience 90: 363-368.

Rouille, Y., Duguay, S.J., Lund, K., Furuta, M., Gong, Q., Lipkind, G., Oliva Jr., A.A., Chan, S.J., and Steiner, D.F. 1995. Proteolytic processing mechanisms in the biosynthesis of neuroendocrine peptides: The subtilisin-like proprotein convertases. Front. Neuroendocrinol. 16: 322-361.

Russo-Neustadt, A., Beard, R.C., and Cotman, C.W. 1999. Exercise, antidepressant medications, and enhanced brain derived neurotrophic factor expression. Neuropsychopharmacology 21: 679-682.

Rutherford, L.C., Nelson, S.B., and Turrigiano, G.G. 1998. BDNF has opposite effects on the quantal amplitude of pyramidal neuron and interneuron excitatory synapses. Neuron 21: 521-530.

Sano, K., Nanba, H., Tabuchi, A., Tsuchiya, T., and Tsuda, M. 1996. BDNF gene can Be activated by $\mathrm{Ca} 2+$ signals without involvement of de novo AP-1 synthesis. Biochem. Biophys. Res. Commun. 229: 788-793.

Schinder, A.F., Berninger, B., and Poo, M.M. 2000. Postsynaptic target specificity of neurotrophin-induced presynaptic potentiation. Neuron 25: $151-163$

Schoups, A.A., Elliott, R.C., Friedman, W.J., and Black, I.B. 1995. NGF and BDNF are differentially modulated by visual experience in the developing geniculocortical pathway. Brain Res. Dev. Brain Res. 86: 326-334

Schuman, E.M. 1999. Neurotrophin regulation of synaptic transmission. Curr. Opin. Neurobiol. 9: 105-109.

Seidah, N.G., Benjannet, S., Pareek, S., Chretien, M., and Murphy, R.A. 1996a. Cellular processing of the neurotrophin precursors of NT3 and BDNF by the mammalian proprotein convertases. FEBS Lett. 379: 247-250.

Seidah, N.G., Benjannet, S., Pareek, S., Savaria, D., Hamelin, J., Goulet, B., Laliberte, J., Lazure, C., Chretien, M., and Murphy, R.A. 1996b. Cellular processing of the nerve growth factor precursor by the mammalian pro-protein convertases. Biochem. J. 314: 951-960.

Senger, D.L. and Campenot, R.B. 1997. Rapid retrograde tyrosine phosphorylation of trkA and other proteins in rat sympathetic neurons in compartmented cultures. J. Cell Biol. 138: 411-421.

Sherwood, N.T. and Lo, D.C. 1999. Long-term enhancement of central

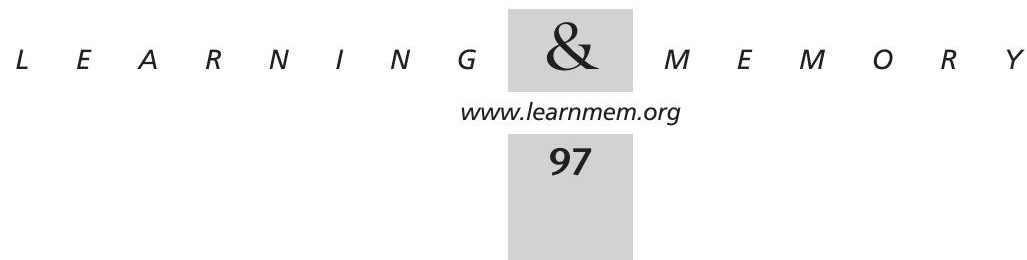


synaptic transmission by chronic brain- derived neurotrophic factor treatment. J. Neurosci. 19: 7025-7036.

Shieh, P.B., Hu, S.C., Bobb, K., Timmusk, T., and Ghosh, A. 1998. Identification of a signaling pathway involved in calcium regulation of BDNF expression. Neuron 20: 727-740.

Smith, M.A. and Cizza, G. 1996. Stress-induced changes in brain-derived neurotrophic factor expression are attenuated in aged Fischer 344/N rats. Neurobiol. Aging 17: 859-864.

Smith, M.A., Makino, S., Kvetnansky, R., and Post, R.M. 1995. Stress and glucocorticoids affect the expression of brain-derived neurotrophic factor and neurotrophin-3 mRNAs in the hippocampus. J. Neurosci. 15: $1768-1777$.

Sorkin, A. and Waters, C. 1993. Endocytosis of growth factor receptors. BioEssays 15: 375-382.

Stent, G. 1973. A physiological mechanism for Hebb's postulate of learning. Proc. Natl. Acad. Sci. 70: 997-1001.

Steward, O. and Schuman, E.M. 2001. Protein synthesis at synaptic sites on dendrites. Ann. Rev. Neurosci. 24: 299-325.

Stoop, R. and Poo, M.M. 1995. Potentiation of transmitter release by ciliary neurotrophic factor requires somatic signaling. Science 267: 695-699.

Tabuchi, A., Nakaoka, R., Amano, K., Yukimine, M., Andoh, T., Kuraishi Y., and Tsuda, M. 2000. Differential activation of brain-derived neurotrophic factor gene promoters I and III by Ca2+ signals evoked via L-type voltage-dependent and $\mathrm{N}$-methyl-D-aspartate receptor $\mathrm{Ca} 2+$ channels. J. Biol. Chem. 275: 17269-17275.

Tao, X., Finkbeiner, S., Arnold, D.B., Shaywitz, A.J., and Greenberg, M.E. 1998. Ca2+ influx regulates BDNF transcription by a CREB family transcription factor-dependent mechanism. Neuron 20: 709-726.

Tao, X., West, A.E., Chen, W.G., Corfas, G., and Greenberg, M.E. 2002. A calcium-responsive transcription factor, CaRF, that regulates neuronal activity-dependent expression of BDNF. Neuron 33: 383-395.

Tartaglia, N., Du, J., Neale, E., Tyler, W.J., Pozzo-Miller, L., and Lu, B. 2001. Protein synthesis dependent and independent regulation of hippocampal synapses by brain-derived neurotrophic factor. J. Biol. Chem. 276: 37585-37593.

Thoenen, H. 1995. Neurotrophins and neuronal plasticity. Science 270: 593-596.

Timmusk, T., Palm, K., Metsis, M., Reintam, T., Paalme, V., Saarma, M. and Persson, H. 1993. Multiple promoters direct tissue-specific expression of the rat BDNF gene. Neuron 10: 475-489.

Timmusk, T., Belluardo, N., Persson, H., and Metsis, M. 1994 a. Developmental regulation of brain-derived neurotrophic factor messenger RNAs transcribed from different promoters in the rat brain. Neuroscience 60: 287-291.

Timmusk, T., Persson, H., and Metsis, M. 1994b. Analysis of transcriptional initiation and translatability of brain-derived neurotrophic factor mRNAs in the rat brain. Neurosci. Lett. 177: 27-31.

Timmusk, T., Lendahl, U., Funakoshi, H., Arenas, E., Persson, H., and Metsis, M. 1995. Identification of brain-derived neurotrophic factor promoter regions mediating tissue-specific, axotomy-, and neuronal activity-induced expression in transgenic mice. J. Cell Biol. 128: 185-199.

Tongiorgi, E., Righi, M., and Cattaneo, A. 1997. Activity-dependent dendritic targeting of BDNF and TrkB mRNAs in hippocampal neurons. J. Neurosci. 17: 9492-9505.

Ueyama, T., Kawai, Y., Nemoto, K., Sekimoto, M., Tone, S., and Senba, E.
1997. Immobilization stress reduced the expression of neurotrophins and their receptors in the rat brain. Neurosci. Res. 28: 103-110.

Vicario-Abejon, C., Collin, C., McKay, R.D., and Segal, M. 1998. Neurotrophins induce formation of functional excitatory and inhibitory synapses between cultured hippocampal neurons. J. Neurosci. 18: $7256-7271$

Villarreal, D.M., Do, V., Haddad, E., and Derrick, B.E. 2002. NMDA receptor antagonists sustain LTP and spatial memory: Active processes mediate LTP decay. Nature Neurosci. 5: 48-52.

Wang, T., Xie, K.W., and Lu, B. 1995. Neurotrophins promote maturation of developing neuromuscular synapses. J. Neurosci. 15: 4796-4805.

Wang, X.H. and Poo, M.M. 1997. Potentiation of developing synapses by postsynaptic release of neurotrophin-4. Neuron 19: 825-835.

Wang, X., Berninger, B., and Poo, M. 1998. Localized synaptic actions of neurotrophin-4. J. Neurosci. 18: 4985-4892.

Wetmore, C., Olson, L., and Bean, A.J. 1994. Regulation of brain-derived neurotrophic factor (BDNF) expression and release from hippocampal neurons is mediated by non-NMDA type glutamate receptors. $J$. Neurosci. 14: 1688-1700.

Xie, K., Wang, T., Olafsson, P., Mizuno, K., and Lu, B. 1997. Activity-dependent expression of NT-3 in muscle cells in culture Implication in the development of neuromuscular junctions. $J$. Neurosci. 17: 2947-2958.

Xu, B., Gottschalk, W., Chow, A., Wilson, R.I., Schnell, E., Zang, K., Wang, D., Nicoll, R.A., Lu, B., and Reichardt, L.F. 2000. The role of brain-derived neurotrophic factor receptors in the mature hippocampus: Modulation of long-term potentiation through a presynaptic mechanism involving TrkB. J. Neurosci. 20: 6888-6897.

Yang, F., He, X., Feng, L., Mizuno, K., Liu, X., Russell, J., Xiong, W., and Lu, B. 2001. PI3 kinase and IP3 are both necessary and sufficient to mediate NT3-induced synaptic potentiation. Nature Neurosci. 4: $19-28$

Young, D., Lawlor, P.A., Leone, P., Dragunow, M., and During, M.J. 1999. Environmental enrichment inhibits spontaneous apoptosis, prevents seizures and is neuroprotective. Nature Med. 5: 448-453.

Zafra, F., Hengerer, B., Leibrock, J., Thoenen, H., and Lindholm, D. 1990. Activity-dependent regulation of BDNF and NGF mRNA in the rat hippocampus is mediated by non-NMDA glutamate receptors. EMBO J. 9: 3545-3550.

Zafra, F., Castren, E., Thoenen, H., and Lindholm, D. 1991. Interplay between glutamate and $\gamma$-aminobutyric acid transmitter systems in the physiological regulation of brain-derived neurotrophic factor and nerve growth factor synthesis in hippocampal neurons. Proc. Natl. Acad. Sci. 88: 10037-10041.

Zafra, F., Lindholm, D., Castren, E., Hartikka, J., and Thoenen, H. 1992. Regulation of brain-derived neurotrophic factor and nerve growth factor mRNA in primary cultures of hippocampal neurons and astrocytes. J. Neurosci. 12: 4793-4799.

Zhang, Y., Moheban, D.B., Conway, B.R., Bhattacharyya, A., and Segal, R.A. 2000. Cell surface Trk receptors mediate NGF-induced survival while internalized receptors regulate NGF-induced differentiation. $J$. Neurosci. 20: 5671-5678.

Zhao, L.R., Risedal, A., Wojcik, A., Hejzlar, J., Johansson, B.B., and Kokaia, Z. 2001. Enriched environment influences brain-derived neurotrophic factor levels in rat forebrain after focal stroke. Neurosci. Lett. 305: 169-172. 


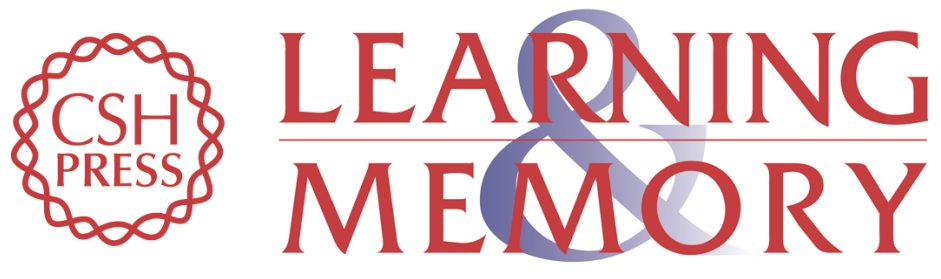

\section{BDNF and Activity-Dependent Synaptic Modulation}

Bai Lu

Learn. Mem. 2003, 10:

Access the most recent version at doi:10.1101/Im.54603

References This article cites 192 articles, 80 of which can be accessed free at: http://learnmem.cshlp.org/content/10/2/86.full.html\#ref-list-1

License

Email Alerting Receive free email alerts when new articles cite this article - sign up in the box at the Service top right corner of the article or click here. 